\title{
Assessing the Implementation of Legal Frameworks on Current Records Management in Public Offices: A Case of Business Registration and Licensing Agency (BRELA)
}

\author{
Lameck Sospeter Kashaija \\ Tanzania Public Service College, P.O box 1534, Singida Tanzania
}

\begin{abstract}
The main objective of this study was to assess the implementation of existing legal frameworks in the management of records at Business Registration and Licensing Agency (BRELA) in Tanzania. Specifically, the study aimed at finding the use of record management legal frameworks in records creation and capturing, classification, tracking and use, and records storage and protection at BRELA. The study targeted a population of 88 staff members of BRELA from whom, 40 respondents were purposively sampled. Qualitative data were collected through interview and observation while quantitative data were collected by using questionnaires. The study reveals that, BRELA has failed to implement the legal frameworks effectively in its records creation and capture, classification, tracking and use, storage and protection. The study recommends that BRELA's top management should prioritise its record management unit to ensure effective record management. BRELA should adopt keyword filing classification system as stipulated by Registry procedures manual of 2007, and establishing guidelines and standards for records security, documenting and implementing disaster preparedness and vital records plan, procedures for access control with assistance from RAMD.
\end{abstract}

Keywords: Legal frameworks, Record practitioners, Records management practices, Policy, Regulations, Guidelines

DOI: $10.7176 / \mathrm{IKM} / 9-11-02$

Publication date: December $31^{\text {st }} 2019$

\subsection{Introduction}

Record management as a sensitive field in any organization needs a lot of attention. Records ensure that evidence and other information needed to support transactions pertaining to individuals and organizations are available. Mnjama \& Wamukoya (2007) hold that government records provide evidence on past decisions and transactions, and ensure rights of both governors and the governed are protected. Ndenje-Sichalwe (2010) in Maseh \& Mutula (2015:21) added that record management is a corporate function like others such as finance management, and human resource management. Maseh \& Mutula (2015) stipulated that like other fields, record management needs to be guided by legal frameworks including policies, Acts, regulations, and guidelines to ensure effectiveness. Legal frameworks regulate actions and procedures followed by record management professionals and ensure effective record management. Therefore, the availability and implementation of record management policies, Acts, regulations and guidelines are core determinants of record management. It is to this fact, initiatives by various governments worldwide to develop record management policies and legislations to guide practices in their governance can be attributed. Such initiatives have been made globally, in Africa, and Tanzania in particular, to ensure that there are legal frameworks to guide record management practices.

In 2001, the International Standard Organization (ISO) developed ISO 15489-Information and Documentation-Record Management as an international standard for good record management practices in both private and public organizations. Smith (2007) revealed that public authorities in the United Kingdom developed policy statements that guide the implementation of Code of Practice on the management of records under the Freedom of Information (FOI) Act 2000. The code of practice aimed at providing a framework to support standards and provide guidance on documenting record practitioners' actions, keeping and disposing records by complying with laws. Other legislations developed by the UK include the Public Records Act 1958 that guided and insisted on preserving records of continuing value in the National Archives for access. The FOI Act of 2000 aims at disclosing information pertaining to public actions to promote transparency and accountability in government agencies. Likewise, the federal government of Canada formulated different legislations such as National Archives Act of 2004, Personal Information Protection and Electronic Documents Act of 2000, Access to Information Act of 2000, and Privacy Act 2004 for better management of records and archives (Miller, 2004). The legislations aimed to protect personal records and privacy of individuals, to legalize the use of electronic records as evidence and ensure freedom of information to the public.

After independence, record management in most African countries faced challenges such as failure to cope with colonial record management systems, backlogs and inadequate skilled personnel. For such reasons, South Africa established statutory and regulatory frameworks for record management. For instance, South African Constitution of 1996 has section 195 which insists on timely, accessible and accurate information for public 
administration and accountability (National Archives and Records Services of South Africa, 2016). The South African government also developed the National Archives and Records Service of South Africa Act. No. 43 of 1996, section 13 of the Act as amended 2000 and regulations of 2002 for efficient record management in governmental bodies. Other legal frameworks in the country include the Promotion of Access to Information Act No. 2 of 2000 established to promote transparency, accountability and good governance, and the Electronic Communications and Transactions Act No. 25 of 2002 for electronic record management (National Archives and Records Services of South Africa, 2016).

In East Africa, several initiatives have been made to establish legal frameworks for record management and archives administration. Maseh (2016) asserted that due to the failure to comply with legal frameworks in managing records, public offices in Kenya are in danger of losing vital public records. As a result, people are likely to be denied their rights, confidentiality agreements will be breached, there will be failure to provide evidence when faced with litigation and there will be poor service delivery because of lack of clear guidance. Recognizing these threats, record management legislations, policies and procedures have been developed and enacted to rescue the situation. For instance, In the Kenyan constitution of 2010, this allows access to information held by the government (Kemoni \& Ngulube, 2007). Other legislations on record management and archive administration developed in Kenya include the Public Archives and Documentation Service Act Cap 19 of 1965 for public records and archives management and Records Disposal Act Cap 14 of 1962 which stipulates records retention periods and disposal criteria (Kemoni \& Ngulube, 2007). Similarly, Ugandan government established its Records and Archives Act of 2001, Act for Records and Archives Management, and Local Government Act, 1997 amended in 2001 to ensure accountability by documenting and keeping records (Obura, 2007). The government of the United Republic of Tanzania (URT) initiated the Records and Archives Management Act No.3 of 2002 and its regulations of 2007, ICT policy of 2003, National Records and Archives Management Policy of 2011 and Registry Procedures Manual of 2007 to guide best practices. BRELA needs an effective record management program to ensure all records of registered companies, granted patents and issued licenses are available and maintained for better and consistent decision making. As it was reported by IRMT (2011) in MDAs that, despite the developed legal frameworks, there is a problem of poor record management resulted from ineffective implementation of legal frameworks. Due to such fact, there is a need to investigate the problem in BRELA. BRELA is the only agency entrusted by the URT government to ensure all business entities are operating under legal registration hence the need for effective record management by complying with legal frameworks to address challenges facing records management

\section{Conceptualization of Terms, Legal and Regulatory Frameworks in Tanzania \\ 2.1.Legislations}

Legislations are Acts, regulations and guidelines enacted by a legislative body in a given place which are meant to be followed by citizens (Mhina, 2012).

\subsection{Record Management Policy}

Record management policy is a formal outline of principles, practices, and procedures for managing records and archives in organization (Maseh \& Mutula, 2015).

\subsection{Regulations}

Regulations are rules that specify mandatory legal requirements showing what to do, how to do it, with a regard to required laws (Sapru, 2004).

\subsection{Record Management Standards}

A standard is an agreed and approved methodology to measure the quality of record management (Mhina, 2012).

\subsection{Legal and Regulatory Frameworks in Tanzania}

The government of the United Republic of Tanzania (URT) initiated record management legal frameworks by formulating the National Archives Management Act of 1965 which replaced the Records (Disposal) Ordinance of 1931. The Act led to the establishment of the National Archives Department which was tasked with acquisition and preservation of public archives (Magaya\& Lowry, 2011). In particular, the putting in place of Act no. 3 of 1965 was the starting point for improving record management in the country, although the Act still faced many challenges. However, the Act left out current and semi-current records management and only focused on archives management (Magaya\& Lowry, 2011). In 2002, the Records and Archives Management Act No. 3 of 2002 was enacted to replace the National Archives Act No. 33 of 1965 (Kamatula, 2011). This resulted in changing the National Archives department to Records and Archives Management Department (RAMD), a body responsible for coordinating best records keeping practices in public offices (Kamatula, 2011). Later, the Records and Archives Management Regulations of 2007 were formulated in $30^{\text {th }}$ March of the same year to 
implement Act No. 3 of 2002. Also in 2007, the government of URT also developed a Registry Procedures Manual which was followed by Desk Instructions for Registry Staff and Records Users made available in 2009. The Government also later put into action the National Records and Archives Management Policy of 2011 to provide new guidance on records and archives management. This was followed by the Guidelines and Procedures for Managing Personnel Records which were ready in 2013. Apart from these Acts, there are others that although have been put in place for other reasons, they have sections providing guidance on record management. These include the Evidence Act of 1967 as amended in 2002 and 2007, and the National Security Act No.3 of 1970. To the Evidence Act, Section 40 was added to address the usage of electronic evidence in courts of law in Tanzania while Section 5 was added to the National Security Act of 1970 to stress the need for protection of classified information (Mhina, 2012).

\subsection{Statement of the Problem}

The government of URT puts in place various legislations and guidelines which include the Records and Archives Management Act No. 3 of 2002, National Security Act No.3 of 1970, National Records and Archives Management Policy of 2011, Records and Archives Management Regulations of 2007, Registry Procedures Manual of 2007, Desk Instructions for Registry Staff and Records Users of 2009, and Guidelines and Procedures for Managing Personnel records in the Public offices of 2013. However, various researchers (Mwela, 2007; Kamatula, 2010; Kilasi, 2010; Ndenje-Sichalwe, 2010; IRMT, 2011; Ndemanyisho, 2014; and Mohamed, Rashel \& Mwagike, 2017) have revealed that although the government developed legal frameworks, public offices still face poor records management in creation, capturing, receipt, use and classification. Kamatula (2010) revealed that public offices face misfiling of records, mixing records from different subjects in one file, delays in file processing and retrieval, lack of vital records plans, and inadequate availability of personnel records which affects pension payment.

BRELA, like any other agency, creates and receives huge amounts of records in both paper and electronic formats to support its functions, activities, and transactions. These records need to be managed under the guidance of existing record management legal frameworks. Although there are several studies on record management and legal frameworks compliance in the public sector in Tanzania (cf. Simon, 2013; and Kamatula, 2010), none of them revealed anything on whether BRELA manages records under the guidance of legal frameworks in place. The state of implementing legal frameworks for good record management at BRELA is unknown.

This study therefore aims at finding out if BRELA implements these frameworks by examining how records creators, custodians, and users put in practice record management legal frameworks when handling records.

\subsection{Aim of the Study}

The main objective of this study was to assess the implementation of existing legal frameworks pertaining to record management at BRELA in Tanzania.

\subsection{Objectives of the Study}

1. Determine the use of the existing legal frameworks in creating and capturing records at BRELA.

2. Determine the use of the existing legal frameworks in classifying records at BRELA.

3. Determine the use of the existing legal frameworks in tracking and use of records at BRELA.

4. Determine the use of the existing legal frameworks on records storage and protection at BRELA.

\section{METHODOLOGY}

The researcher employed case study design as a means of in-depth investigation of problem at BRELA as the only agency entrusted by the URT government to ensure all business entities are operating under legal registration, hence the need for effective record management by complying with legal frameworks. Case study design was recommended by Wiersma \& Jurs (2009) that is a detailed and comprehensive design for examination of something in one organization or unit. The mixed approach was used, where by qualitative data were collected through interview and observation methods, while quantitative data were collected through questionnaires. Documentary review method was used to complement the collected primary data. Interview was conducted to 4 respondents, and questionnaire method was used to collect data from 36 respondents. The researcher selected the sample of 40 respondents purposively from the population of 88 employees because records practitioners at BRELA were not exceeding 40 employees. Therefore, all 40 key informants were selected by researcher though 8 respondents did not respond to questionnaires. The sample size was formed by 1 CEO, 4 Directors, 1 Records Officer, 17 Records Management Assistants, 1 Principle Human Resource Officer, and 14 Action Officers from units, 1 Secretary and 1 Office Attendant. Interview was conducted to 1CEO, 1 Record officer, 1Records Management Assistant and 1 Principle Human Resource Officer. Questionnaires were distributed to 4 Directors, 16 Records Management Assistants, 14 Action officers, 1 secretary and 1 Office 
Attendant.

\section{Findings and Discussion}

\subsection{The Use of Legal Frameworks on Records Creation and Capturing at BRELA}

Record management legal frameworks make it a mandatory requirement that each public office should create and keep adequate records to support its business activities. The National and Records and Archives Management Policy of 2011, under policy issue No.3, "Deployment of new technology in the management of records and archives" requires public offices to create and manage electronic records for easy access by the government. Also, ISO 15489-2001 requires creation of guidelines and procedures to guide records creation. Based on this, the researcher asked all respondents the format in which records were created and received at BRELA. The question aimed at determining if BRELA created and received paper or electronic records, or both paper and electronic records. Table 4.1 summarizes the responses provided.

Table 4.1: Formats of Records created and received at BRELA

\begin{tabular}{|c|c|c|c|}
\hline \multirow{3}{*}{$\begin{array}{c}\text { ample total } \\
(\mathbf{N}=\mathbf{2 8})\end{array}$} & Format & Frequency & Percent \\
\cline { 2 - 4 } & Paper format & 4 & $14.2 \%$ \\
\cline { 2 - 4 } & Electronic format & 6 & $21.4 \%$ \\
\cline { 2 - 4 } & Hybrid (both paper and electronic format) & 18 & $64.3 \%$ \\
\hline
\end{tabular}

Source: Field Data, 2019

The results in Table 4.1 indicate that 18 (64.3\%) respondents said they create and receive records in paper and electronic formats, $6(21.4 \%)$ respondents said they create and receive them in electronic format, and 4 $(14.2 \%)$ respondents said they create and receive them in paper format only. In general, these results seem to imply that BRELA creates and receives records in both paper and electronic formats. The few respondents who indicated that they create records in either print or electronic format are likely to be responsible for activities that are either entirely paper or electronic based. The apparent high acceptance of e-records at BRELA was during interviews, and this was attributed to the introduction of an Online Registration System (ORS) for registering new companies. It was reported during interviews that since the introduction of the system, the institution has been prioritizing electronic record management. Speaking on this, one interviewee shared the following:

...we decided to introduce online registration system in order to decentralize services to our customers.

With this approach, there is no need for a customer from Namtumbo to come to Dar es Salaam for business registration...

The researcher also asked respondents if there were any documented guidelines or procedures that guided them on the format in which they have to create and retain records. In response to this question, 25 (89.3\%) respondents said there were no such guidelines while $3(10.7 \%)$ said that guidelines were present. From these results, it can be concluded that BRELA does not have written guidelines for records creation and receipt. The few respondents who answered that such guidelines exist referred to unwritten procedures they use during creation of records. When researcher asked about guidelines available, one interviewee responded that:

... We use normal procedures of creating files as instructed by supervisor but yet are not documented anywhere..

The study also looked at BRELA's ability to abide to the Guidelines and Procedures for Managing Personnel Records in Public Offices of 2013. To do so, the record practitioners involved in interviews were asked if BRELA created personal files such as master and confidential files. Although the interview revealed that BRELA creates master and working files for each employee, it was noted that there was no guiding document used to do so. Responding to a question on this, one interviewee had this to say:

...there is no any guideline which guides us on human resource records; we follow the normal procedures

instructed by supervisor of creating two files for each employee as a culture of our institution...

These results show that BRELA has failed to meet requirements of ISO 15489-2001 by failing to develop guidelines and procedures for records creation. The results have also shown that there are variations with regards to the format in which records are created and received at BRELA due to lack of guidelines. Also, only personal files were created at BRELA, there were no subject personnel files. This can be attributed to the absence of Guidelines and Procedures for Managing Personnel Records in the Public Offices of 2013. The guidelines require the creation of two main categories of personnel files namely; subject personnel files and personal files. Personal files are further divided into working/open files and master/confidential files. According to interviewees, BRELA only creates personal files (master and working files) and interviewees did not know subject personnel files. The lack of knowledge on these types of files, coupled with the BRELA'S failure to create them is clear results of the absence of Guidelines and Procedures for Managing Personnel Records in Public offices of 2013.

Based on these findings, BRELA creates and receives records without referring to documented guidelines. As a result, Guidelines and Procedures for Managing Personnel Records in Public offices of 2013 are not well adhered to. The state reported in these results has implications on personnel record management. The findings 
are similar to what Mutula \&Mostert (2010) observed in their study. The researchers found that policies and regulatory frameworks put in place by the government of South Africa are yet to be implemented effectively by people responsible for creating and managing records in order to enhance service provision to citizens. Similarly, Kamatula (2010) attributed poor record management as he found that UDSM managed records without following existing legal frameworks.

\subsection{The Use of Legal Frameworks on Records Classification at BRELA}

It is a legal requirement of every public office to classify records for easy access. Therefore, in addition to ensure that records are created following available frameworks, BRELA has the responsibility of ensuring easy access. It was one of the intentions of this study to find out if BRELA classifies records according to requirements. As a result, record personnel were asked about the kind of classification system used to arrange records. This was done with an expectation that it will help to determine if BRELA adheres to Registry Procedures Manual of 2007 which requires that records must be classified by using a keyword filing system. The responses obtained were as presented in the table 4.2:

Table 4.2: Records Classification Systems at BRELA

\begin{tabular}{|c|c|c|c|}
\hline \multirow{4}{*}{$\begin{array}{c}\text { Sample total } \\
(\mathbf{N}=\mathbf{1 6})\end{array}$} & Record management system & Frequency & Percent \\
\cline { 2 - 4 } & Key word system & 0 & $0 \%$ \\
\cline { 2 - 4 } & Numerical system & 2 & $12.5 \%$ \\
\cline { 2 - 4 } & Alphabetical system & 1 & $6.3 \%$ \\
\cline { 2 - 4 } & Alphanumerical & 0 & $81.3 \%$ \\
\cline { 2 - 4 } & Subject system & $0 \%$ \\
\hline
\end{tabular}

Source: Field Data, 2019

Results in Table 4.2 indicate that $13(81.3 \%)$ respondents said BRELA classifies records using an alphanumerical system, $2(12.5 \%)$ said that the classification is numerical while $1(6.3 \%)$ respondent said an alphabetical system is used. The results seem to imply that BRELA employs an alphanumerical system to classify its records instead of the recommended keyword filing classification system. The respondents who mentioned other systems were more likely unable to differentiate alphanumerical system and two systems mentioned. This was confirmed when researcher wanted to confirm the variation from one interviewee, the response was;

...some staff consider numerical, alphabetical and alphanumerical as on system ... they fail to differentiate them...

BRELA's usage of an alphanumerical filing classification system to classify its records was confirmed through observations. During interviews, when researcher wanted to know why BRELA has failed to establish keyword system, one respondent talked about prospects of using keyword system as follows:

...in 2016 we proposed the establishment of a keyword filing classification system but we failed to launch it because the organization lacked organizational structure for establishing it. As a result, all efforts made were in vein...

When researcher asked if there was any policy or guideline that specified the records classification system for classifying records at BRELA, majority $14(87.5 \%)$ of respondents said there was none. This was confirmed through observations. However, during interviews, interviewees said the decision to use alphanumeric filing system was influenced by the Company Act for business file classification. On this, one interviewee shared the following:

...we are guided by Companies Act to classify and arrange documents in business records files. Under this system, one file is divided into two parts; part one files correspondence and part two files attachments...

As stated earlier, the Registry Procedures Manual of 2007 clearly specifies the need for public offices to use keyword filing classification system in classifying their records. Therefore, BRELA's failure to implement this classification system is a clear indication of its failure to abide to the requirements of this Manual. This is likely to result in poor records filing. Similarly, Marutha (2011) observed that public offices in South Africa experienced poor record management as a result of lack of implementing legal frameworks. Chachage \&Ngulube (2006) also found that the usage of numerical and alphanumerical systems by most public offices resulted in poor records keeping. On their part, Kamatula (2010) and Simon (2013) reported that in Tanzanian public offices records are managed with reliance on personal professional experiences rather than following legal frameworks.

\subsection{The Use of Legal Frameworks on Records Use and Tracking at BRELA}

Considering that records are kept for daily use in any organization, legal frameworks require public offices to have file movement control systems to help them in controlling the movement of these resources. On this, policy issue No. 5 "Tracking and use of records and archives" of the National Records and Archives Management Policy of 2011 requires public offices to establish file movement control systems. The policy issue requires the creation of control tools for file retrieval, use, and tracking. The system ensures a record has been captured into 
the records keeping system after being retrieved and used. This study looked at the existing file movement control system at BRELA to determine if the requirements specified by legal frameworks are met. The first question record personnel were asked was meant to help to determine if BRELA has file index or register for record files created in its registries. Results show that $14(85.5 \%)$ respondents said that there were registers for all records files created at BRELA while only $2(12.5 \%)$ respondents indicated otherwise. Therefore, these findings show that there are registers for files generated at BRELA. During observations, the researcher was able to look at one register for records files pertaining to registered companies

Another question was directed to records personnel, action officers, the secretary and the office attendant. The question required the respondents to identify file movement tools used in the daily handling of record files. The tools identified are as shown in Table 4.3:

Table 4.3: Files movement Control Tools at BRELA

\begin{tabular}{|c|c|c|c|}
\hline \multirow{4}{*}{$\begin{array}{c}\text { Sample total } \\
\text { (N=28) }\end{array}$} & File movement control tool & requency & Percent \\
\cline { 2 - 4 } & File requisition management system (FIRMS) & 25 & $89.3 \%$ \\
\cline { 2 - 4 } & Transit sheet & 16 & $57.2 \%$ \\
\cline { 2 - 4 } & Transit ladder & 16 & $57.2 \%$ \\
\cline { 2 - 4 } & File diary & 16 & $57.2 \%$ \\
\cline { 2 - 4 } & File index & 16 & $57.2 \%$ \\
\hline
\end{tabular}

Source: Field Data, 2019

The results show that there are a total of five records movement control tools used at BRELA. One of these is an automated file movement system. One interviewee shaded light on this as follows:

...we have an electronic file movement control system which is able to determine where a manual file is located, which file is restricted for investigation, who was the last person to access a file, and at what time and date a file was last accessed...

During the interviews, it was also noted that, although BRELA has a good automated file movement control system, there are still some cases of files being lost because of action officers' failure to use the system. This was brought up by one respondent who said that:

...despite the fact that BRELA has an effective automated file movement system, we have cases of losing

files because there is still lack of awareness and knowledge on the usage of the system...

The third question asked was directed to action officers. The question required them to indicate the extent to which they were satisfied with services provided by record management unit particularly on records retrieve and use. The aim was to know to what extent the available file movement system is helpful to satisfy the need of users. The results show that $7(70 \%)$ respondents said they were somehow satisfied with services provided by the record management unit, $2(20 \%)$ said they were satisfied by the services while $1(10 \%)$ was not satisfied. In general, these results show that action officers are somehow satisfied with services provided by the BRELA's records unit. Satisfaction was minimum despite the establishment of a system for file movement that includes file movement tools such as register, FIRMS, transit ladder and transit sheet as observed by researcher.

Considering the records movement and tracking tools identified by this study, it can be concluded that BRELA has managed to adhere to National Records and Archives Management Policy of 2011 and Registry Procedures Manual of 2007 requirements for good file movement control system. During observation it was noted that BRELA has established an automated file movement control system (File Requisition Management System) used to request files from the registry. The system records the requisition officer, date and time of requesting, and retrieves and returns the particular file(s). Although BRELA has succeeded to have a file movement control system, there were no organizational guidelines, procedures, and standards to facilitate the usage established system. This explains the misplacement of files reported by interviewees. These results echo those reported by Tsholo \&Mnjama (2010) in Gaborone city, Botswana. The researchers found losses and misplacement of files due to lack of effective tools for monitoring file movement.

\subsection{The Use of Legal Frameworks on Records Storage and Protection at BRELA}

Record management legal frameworks such as Records and Archives Management Act No.3 of 2002 and its regulations of 2007, National Records and Archives Management Policy of 2011, and ISO 15489 require public offices to ensure good security of records against disaster and unauthorized access. With the intention of finding out if BRELA's management of records is in line with the requirements of these tools, record personnel were asked if there was a documented vital records recovery plan in their offices. The response shows that $13(81.3 \%)$ respondents replied that there was no documented vital records recovery plan while only $3(18.8 \%)$ said a written vital records recovery plan was available. When respondents were asked if there was any policy or guideline on vital records was available, $16(100 \%)$ respondents revealed that there was none. Similarly, when action officers were asked if a policy or guidelines for records security were present all $10(100 \%)$ of them said there was not document of such nature. Data obtained through interviews supported what was found from questionnaires. During the interviews, one respondent said: 
...although we take some precautions on vital records like storing them in cupboards, there is no specific guideline or a written plan for the management of vital records to ensure their protection...

Another question the researcher asked was on the presence of a documented disaster preparedness plan. The respondents show that there was no documented disaster preparedness plan at BRELA. Of the records personnel that responded to this question, $13(81.3 \%)$ said there was no plan while $3(18.8 \%)$ said such a document was present. From interviews, it was confirmed that there was no disaster preparedness plan. Responding to a question on this, one interviewee said:

...there are some precautions we take in case of disasters. For example, we have fire extinguishers, fire

alarm, and smoke detectors. However, we don't have any written disaster preparedness plan...

Understandably, the researcher was unable to locate a disaster preparedness plan. However, the researcher noticed various precautionary measures in place as preparedness for disasters.

The respondents were also asked about the availability of written guidelines on restrictions of access to records in management and departmental units. The responses show that $25(89.3 \%)$ respondents said that there were no such guidelines while $3(10.7 \%)$ said such guidelines were available. Similarly, the researcher was not able to confirm the availability of access restriction or security guidelines at BRELA. When researcher asked why BRELA has neither a written vital plan nor disaster preparedness plan, one interviewee responded that:

... The management is satisfied by precautions made such as fire extinguisher, alarms....also lack of resources affect the process...

And that was a reason to some respondents to claim that BRELA has vital and disaster preparedness plan.

Another question directed to record personnel was aimed at determining if BRELA provided facilities for ensuring the security of records. According to responses, $14(87.5 \%)$ record personnel stated that their office provided storage facilities such as safes, cabinets, and shelves while $2(12.5 \%)$ said that the office did not provide adequate facilities for ensuring records security. Although majority of respondents said that storage facilities were provided, observations showed that the facilities did not have enough space to house all the available records. Based on the above results, it can be concluded that BRELA does not comply with records storage and protection requirements stipulated in legal frameworks.

Still on records protection, a question was asked with an aim of determining if BRELA classifies records based on sensitivity (i.e. Top secret, secret, and confidential). The RAM Act No. 3 of 2002 emphasizes classification and protection of sensitive records (records pertaining to national security, maintenance of public order, revenue, and individual privacy). Similarly the National Security Act of 1970 section 5 also emphasizes the classification and protection of classified records. To find out if BRELA complied with these legal frameworks, respondents were asked if they classified records based on how sensitive they are. The results indicate that $12(42.9 \%)$ respondents said that records were classified as top-secret, secret and confidential while $16(57.1 \%)$ respondents said such a classification approach was not in use. The researcher decided to confirm the above results through interviews and observations. During interviews, respondents revealed that records were only being classified as confidential or open, rather than as top secret and secret information. One interviewee shared the following:

...BRELA lacks a confidential registry. We classify some files as confidential. Some of these are stored in the CEO's office. Some files are treated as confidential once there is a conflict among shareholders or if there is a case in court...

Based on these results, it can be said that BRELA classifies records as confidential and open files despite being required to do otherwise by legal frameworks. In addition, BRELA's failure to comply with legal frameworks is manifested in the insufficiency of storage facilities, absence of vital records plans and access protection, and a disaster preparedness plan. In all, these results invite questions regarding the safety of records at this institution. From the findings it can be concluded that the likeliness that confidential records will be safe in these offices is low.

Generally, BRELA has failed to ensure good storage and protection of records. This can be associated with the absence of guidelines and procedures, and failure to adhere to national legal frameworks. The results confirm what Ndenje-Sichalwe (2010) and Kilasi (2010) reported. The researchers found that some government ministries in Tanzania did not consider security as a significant part of record management hence they did not put in place any disaster preparedness plans and security measures. Similarly, Ndemanyisho (2014) reported that TRA records are not sufficiently protected since there were no vital records and disaster management plans.

\subsection{Conclusion}

Despite the fact that, BRELA has managed to crate and capture records in both formats, establishment of effective file movement control system, legal frameworks were not effectively implemented. The findings reveal that BRELA does not classify records through keyword filing classification system as mandated by legal frameworks. Although a new file movement system for controlling file movement has been introduced, it is not used effectively because there were no written guidelines and procedures to follow when using it. As a result, 
files are still being lost. There is no effective maintenance and protection of records because BRELA lacks guidelines on records security and access control, and absence of disaster and vital records plan. Therefore, record practitioners at BRELA have failed to put in practices legal frameworks effectively, they manage records by experience and not legal requirement which results to poor records management at BRELA.

\subsection{Recommendations}

Based on the findings, the study recommends that BRELA should adopt keyword filing classification system as stipulated by Registry procedures manual of 2007 with assistance from RAMD. Keyword filing classification system was introduced to address the challenges that other systems faced like alphanumerical system used at BRELA. BRELA should establish guidelines and standards for records security, documenting and implementing disaster preparedness and vital records plan, procedures for access control. The top management should provide adequate and appropriate records storage space and facilities in order to protect records against disaster and unauthorized access. BRELA must construct confidential registry for special management of sensitive records. Confidential registry is featured by vetted employees, grilled windows and doors, not labeled, not easily seen, sound proof and cabinet and safes must be properly bricked in with proper locks. BRELA should adhere to Guidelines and Procedures for Managing Personnel records in the Public offices of 2013 by creating and managing both personal files and subject personnel files.

\section{REFFERENCES}

Chachage, B. \&Ngulube, P. (2006). Management of business records in Tanzania: An exploratory case study of selected companies. South African journal of Information Management 8(3):112-121.

International Records Management Trust; (2011). Managing records as reliable evidence for ICT/ e-Government and Freedom of Information: An East African Regional Situation Analysis. London: IRMT.

Kamatula, A.G. (2011). Marketing and public programming in records and archives at the Tanzania Records and Archives Management Department, Journal of the South African Society of Archivists, 44(1):74-89.

Kamatula, A.G. (2010). Managing records at the University of Dar es salaam, Tanzania. Master of Records and Archives Management Dissertation, University of Botswana, Gaborone.

Kemoni, H.N. \&Ngulube, P. (2007). Records and archives legislation in Kenya and management of public sector Records: A SWOT analysis approach, African Journal of Library, Archives and Information Science, 17(2):89-102.

Kilasi, M.P. (2010). An assessment of disaster preparedness for public sector records management in Tanzania: a case of the president's office public service management and prime minister's office. Master of Records and Archives Management Dissertation, University of Botswana, Gaborone.

Magaya, C. \& Lowry, J. (2011). The National archives of Tanzania fifty years after wright's Report on the government records and public archives of Tanganyika.

Marutha, N.S. (2011), Record management in support of service delivery in the public health sector of the Limpopo province in South Africa. Master of Records and Archives Management Dissertation, University of South Africa

Maseh, E. (2016). E-government implications for Record management in Africa, a review of literature. Journal of the South African Society of Archivists, 49(2): 89-101.

Maseh, E. \&Mutula, S. (2015). Policy, legal and regulatory framework for Record management in the Kenyan judiciary. ESARBICA Journal, 34(1): 21-34.

Mhina, C.A. (2012). Mandatory tools for the management of Records and Archives in Tanzania, Record management Policy, Standards, Act and Regulations. Dar es salaam, Tanzania, Apex Graphics Publishers.

Mohamed, B; Rashel, A \&Mwagike, R. (2017). Management of records in Tanzania: Review and appraisal of applicable theories and examination of selected empirical findings, Journal of Public Administration and Governance 8(1): 51-67.

Miller, C. (2004). Archival legislation in Canada federal government, InterPARES 2 Project,PolicyCrossdomain.Retrievedfromhttp://www.interpares.org/display file.cfm?doc=ip2(policy)archi val legislation_CANADA_FEDERAL.pdf accessed on 3 August 2018.11:24:40.

Mutula, S.M \& Mostert, J. (2010). Challenges and opportunities of e government in South Africa, The Electronic Library 28(1): 38-53.

Mnjama, N. \& Wamukoya, J. (2007). E-government and Record management: an assessment tool for e-records readiness in government. The Electronic Library 25(3): 274-284.

Mwela, A.C. (2007). An Assessment of Impact of records and archives services on public service delivery in Tanzania. Master of Records and Archives Management Dissertation, University of Botswana, Gaborone.

National Archives and Records Services of South Africa, (2016). Record management legal frameworks of South Africa, Department of Arts and Culture, Republic of South Africa Retrieved from https://www.nationalarchives.gov.za/node/422, accessed on 3 August 2018. 
Ndemanyisho, A. J. (2014). Reflecting on revenue collection in Tanzania: What went wrong with records? International Journal of Education and Research, 2(8): 118-126.

Ndenje-Sichalwe, E. N. (2010). The significance of record management to fostering accountability in the public service reform programme of Tanzania, PhD Thesis. University of KwaZulu-Natal; South Africa.

Nengomasha, T. (2013). The past, present and future of records and archives management in sub-Saharan Africa, Journal of the South African Society of Archivists, 46(2):2-11.

Obura, O. (2007). Records and archives legal and policy frameworks in Uganda" Library Philosophy and Practice (e journal).608.

Sapru, R. (2004). Public policy, formulation, implementation and evaluation, New Delhi, Sterling publishers. .

Simon, N.M. (2013). The challenges and the need of legal framework for data protection in Tanzania: case study of Tanzania national identification authority (NIDA). Master Law degree in information technology and telecommunication dissertation. The Open University of Tanzania, Dar es Salaam. .

Smith, K. (2007). Public sector record management; A practical guide. Brighton, Ashgate publishing Limited.

Tshotlo, K. \& Mnjama, N. (2010). Record management audit: the case of Gaborone City Council. ESARBICA Journal 29: (1) 67-86.

Wiersma, W. \&Jurs, S. G. (2009). Research methods in education: An introduction. Boston: Pearson Education, Inc. 